\section{Visible and near infrared spectroscopy for predicting texture in forest soil: an application in southern Italy}

\author{
Massimo Conforti, Raffaele Froio, Giorgio Matteucci, Gabriele \\ Buttafuoco
}

Texture is a primary variable affecting the total amount of carbon stock in the soil. The standard methods for determining soil texture, however, are still conducted manually and are largely time-consuming. Reflectance spectroscopy in the visible, near infrared (Vis-NIR, 350-2500 nm) spectral region could be an alternative to standard laboratory methods. The aim of this paper was to develop calibration models based on laboratory Vis-NIR spectroscopy and PLSR analysis to estimate the texture (sand: 2-0.05 mm; silt: 0.05-0.002 mm; clay: $<0.002 \mathrm{~mm}$ ) in a forest area of southern Italy. An additional objective was to produce continuous maps of sand, silt and clay through a geostatistical approach. Soil samples were collected at 235 locations in the study area, and then dried, sieved at $2 \mathrm{~mm}$ and analyzed in laboratory for soil texture and VisNIR spectroscopic measurements. Spectra showed that soil samples could be spectrally separable on the basis of classes of texture. To establish the relationships between spectral reflectance and soil texture (sand, silt and clay) partial least squared regression (PLSR) analysis was applied to 175 soil samples, while the remaining 60 samples were used to validate the models. The optimum number of factors to be retained in the calibration models was determined by leave-one-out cross-validation. Results of cross validation of calibration models indicated that the models fitted quite well and the values of $R^{2}$ ranged between a minimum value of $0.74 \%$ for silt and a maximum value of 0.84 for sand content. Results for validation were satisfactory for sand content $\left(R^{2}=0.81\right)$ and clay content $\left(R^{2}=0.80\right)$ and less satisfactory for silt content $\left(R^{2}=0.70\right)$. Geostatistics coupled with Vis-NIR reflectance spectroscopy allowed us to produce continuous maps of sand, silt and clay, which are of critical im portance for understanding and managing forest soils.

Keywords: Forest Soils, Soil Texture, Vis-NIR Spectroscopy, Geostatistics, Southern Italy

\section{Introduction}

Carbon storage in forest ecosystems involves carbon in biomass and soil. Interest in the ability of forest soils to sequester atmospheric $\mathrm{CO}_{2}$ derived from fossil fuel combustion has recently increased because of the threat of climate change (Lal 2005). Therefore, understanding the mechanisms and factors of organic carbon dynamics in forest soils is important for identifying and enhancing natural sinks for carbon sequestration, in order to mitigate the effects of climate

change (Lal 2005). The key factors in estimating the potential for organic matter in soil to act as a source or sink of $\mathrm{CO}_{2}$ are the size of the carbon flux into and out to the soil pool, and the residence time of organic matter in the soil (Silver et al. 2000). In relation to the second factor, it is critical to understand how texture and mineralogy influence the residence time of carbon in forest soils. Besides the key role in belowground carbon storage in forest ecosystems, soil texture strongly influences the availability and

$\square$ Institute for Agricultural and Forest Systems in the Mediterranean (ISAFOM), National Research Council of Italy, v. Cavour 4/6, I-87036 Rende (CS, Italy)

@ Gabriele Buttafuoco (gabriele.buttafuoco@cnr.it)

Received: Dec 29, 2013 - Accepted: May 29, 2014

Citation: Conforti M, Froio R, Matteucci G, Buttafuoco G, 2015. Visible and near infrared spectroscopy for predicting texture in forest soil: an application in southern Italy. iForest 8: 339-347 [online 2014-09-09] URL: http://www.sisef.it/iforest/contents/?id=ifor1221-007

Communicated by: Davide Ascoli retention of nutrients, particularly in highly weathered soils (Telles et al. 2003).

Texture refers to the size and distribution of primary soil particles and it is the relative proportion of sand $(2-0.05 \mathrm{~mm})$, silt $(0.05-$ $0.002 \mathrm{~mm})$, and clay $(<0.002 \mathrm{~mm})$ in a given soil, inherited from the parent materials. Soil texture, which originates through weathering and pedogenetic processes (Osman 2013), is not usually changed by land management practices, but it may be altered by erosion, deposition, truncation, landfill, etc. (Buttafuoco et al. 2012, Osman 2013).

Standard methods for determining texture in soils are either the pipette method or the hydrometer method, which are both conducted manually, being hence labor intensive and time-consuming.

Reflectance spectroscopy in the visible, near infrared (Vis-NIR, 350-2500 nm) spectral region could be an alternative to standard laboratory methods, even though soil Vis-NIR spectra are largely non-specific, quite weak and broad due to overlapping absorptions of soil constituents, often present at small concentrations in the soil (Viscarra Rossel \& Behrens 2010). The method is based on the simplified assumption that the soil reflectance in the $350-2500 \mathrm{~nm}$ spectral region is a linear combination of the spectral signatures of its compositional components weighted by their abundance (Curran 1994, Ben-Dor 2002, Ge et al. 2007). Therefore, changes in chemical, physical and mineralogical properties of the soil produce distinct spectral features detectable through reflectance spectroscopy (Ehsani et al. 1999, Leone \& Sommer 2000, Shepherd \& Walsh 2002, Nanni \& Demattê 2006, Viscarra Rossel et al. 2006, Aïchi et al. 2009, Conforti et al. 2012, Conforti et al. 2013a, 2013b).

Vis-NIR spectroscopy requires only a few seconds to measure a soil sample, but the reflectance spectra are largely non-specific due to interference from the overlapping spectra of soil constituents that are themselves varied and interrelated (Viscarra Rossel \& McBratney 2008). Consequently, the relevant information needs to be mathematically extracted from the spectra and correlated with soil properties. Generally, chemometric techniques and multivariate calibrations are used to this purpose (Martens \& Naes 1989, Viscarra Rossel \& Behrens 2010, Stenberg et al. 2010), such as multiple linear regression (MLR), principal components regression (PCR), partial least-squares regression (PLSR) and artificial neural networks (ANN - Chang et al. 2001, Shepherd \& Walsh 2002, Udelhoven et al. 2003, Yang et al. 2003, Viscarra Rossel et al. 2006, Farifteh et al. 2007, Aïchi et al. 2009, McDowell et al. 2012).

Examples of the application of visible and near infrared spectroscopy for predicting soil 


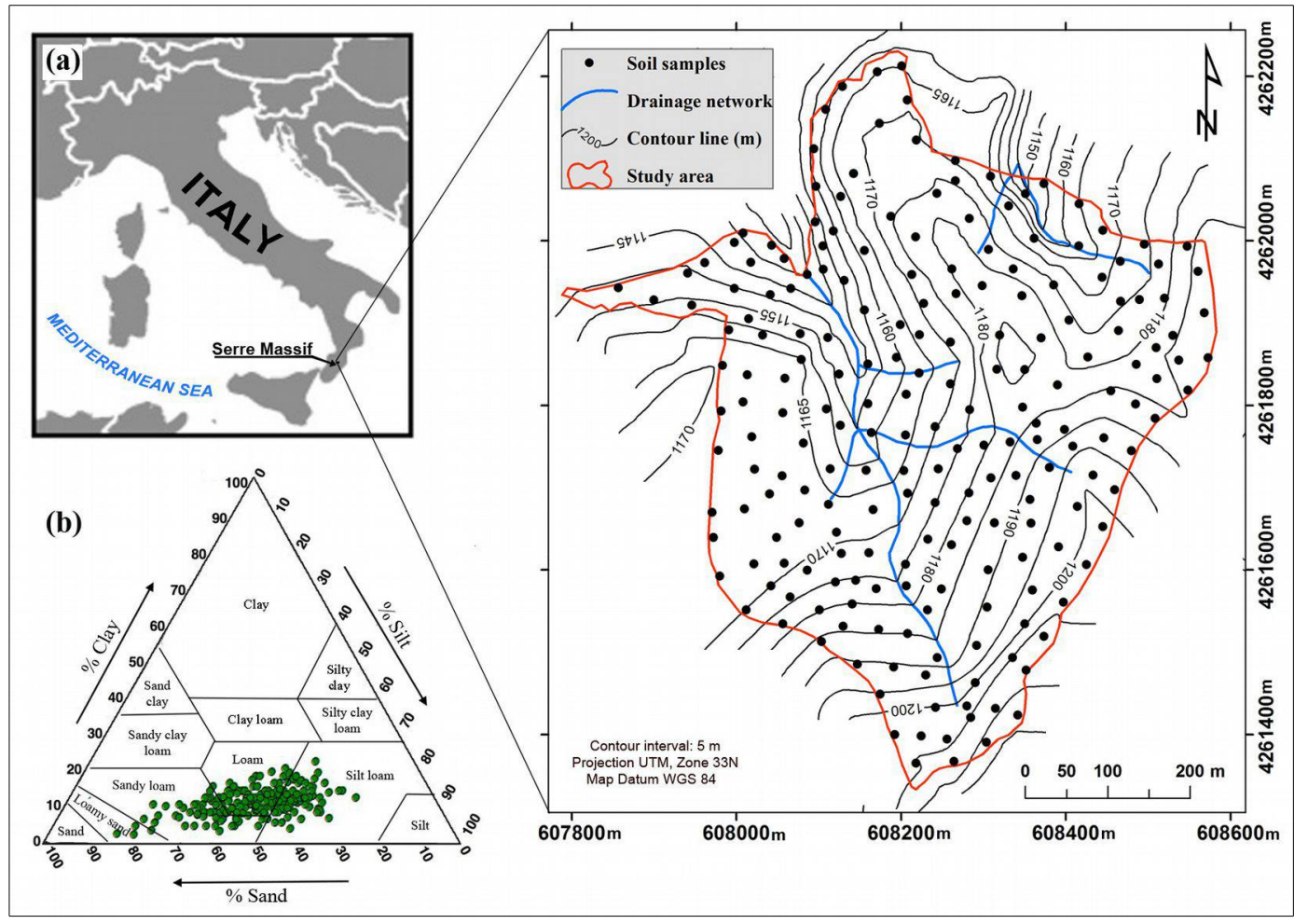

Fig. 1 - (a) Study area and soil sampling locations; (b) soil textural triangle of the percentages of sand (2-0.05 $\mathrm{mm})$, silt $(0.05-0.002 \mathrm{~mm})$ and clay $(<0.002 \mathrm{~mm})$.

clay content only, or the three textural fractions in soil (sand, silt and clay) can be found in Viscarra Rossel \& McBratney (1998), Sørensen \& Dalsgaard (2005), Mouazen et al. 2005, Waiser et al. (2007), Wetterlind et al. (2008), Bricklemyer \& Brown (2010), Conforti et al. (2013b), Curcio et al. (2013), Knadel et al. 2013, among others.

The representation of variability of textural fractions (sand, silt, and clay) is of critical importance for understanding and managing forest soils. Since such fractions are determined only at sampled locations, there is the need to couple the multivariate calibrations approach with geostatistical analysis to produce accurate continuous maps. Geostatistical methods (Matheron 1971) provide a valuable tool to study the spatial pattern of textural fractions, taking into account spatial autocorrelation of data to create mathematical models of spatial correlation structures, commonly expressed by variograms. The interpolation technique of textural fractions at unsampled locations, known as kriging, provides the "best", unbiased, linear estimate of a regionalized variable in an unsampled location, where "best" is defined in a leastsquare sense (Chilès \& Delfiner 2012).

The main objective of this paper was to develop, separately for each soil textural fraction, calibration models based on laboratory Vis-NIR spectroscopy and PLSR analysis in a forest area of southern Italy. An additional objective was to use a geostatistical approach to map the three soil textural fractions (sand, silt and clay).

\section{Material and methods}

\section{Study area}

The study area is a high beech (Fagus sylvatica L.) forest of $332000 \mathrm{~m}^{2}$, located in the Serre Massif (southern Italy - Fig. 1) from $16^{\circ} 14^{\prime} 10^{\prime \prime} \mathrm{E}$ to $16^{\circ} 14^{\prime} 42^{\prime \prime} \mathrm{E}$ of longitude and $38^{\circ} 30^{\prime} 7^{\prime \prime} \mathrm{N}$ to $38^{\circ} 29^{\prime} 31^{\prime \prime} \mathrm{N}$ of latitude. Elevation ranges from 1155 to 1205 $\mathrm{m}$ a.s.l. Slope ranges between 0 to about $45^{\circ}$, whereas the average slope is $10^{\circ}$.

The climate is typical Mediterranean upland (Csb, sensu Köppen 1936) with a longterm (1928-2012) average annual precipitation of $1810 \mathrm{~mm}$ over 110 rainy days, and an average mean annual temperature of $11.3{ }^{\circ} \mathrm{C}$. Yearly rainfall distribution exhibits a peak from November to February when more than $60 \%$ of total annual precipitation occurs.

Concerning the pedoclimate, the study area has a mesic soil temperature regime associated with an udic soil moisture regime (ARSSA 2003).

The geology of the area is characterized by Palaeozoic granitoid rocks deeply fractured and weathered, frequently covered by thick regolith and/or colluvial deposits (Borsi et al. 1976, Calcaterra et al. 1996). Morphologically, the study area is dominated by a mountains landscape with deep, V-shaped valleys and top paleosurfaces, representing the residual flat or gently-sloping highlands, often separated by steep slopes (SorrisoValvo 1993, Calcaterra \& Parise 2010).

Soils are relatively young, from poorly to moderately differentiated, and heavily dependent on the nature of the parent rock and the climatic conditions. Based on the USDA (2010) soil classification, most of the soil types belong to Entisol and Inceptisol orders (ARSSA 2003). The soil depth ranges from shallow to moderately deep $(0.20$ to $1 \mathrm{~m})$ with profiles characterized by A-Bw-Cr horizons and/or A-Cr horizons (ARSSA 2003). Moreover, the upper A horizon (Umbric epipedon - USDA 2010) shows a very dark brown color due to the accumulation of organic matter.

\section{Soil sampling}

Soil samples were collected in October 2012 at 235 locations within the study area (Fig. 1a). Soil depth sampling was set at 0.20 $\mathrm{m}$, measured from the base of organic horizons, which were removed. Soil was sampled in a metallic core cylinder with a diameter of $7.5 \mathrm{~cm}$ and height of $20 \mathrm{~cm}(883.6$ $\mathrm{cm}^{3}$ ). Sampling locations were geo-referenced by a differential global positioning system (DGPS) with a precision of about $1 \mathrm{~m}$.

\section{Texture analysis}

Prior to the texture analysis and Vis-NIR spectroscopic measurements, samples were oven dried at $45^{\circ} \mathrm{C}$ for 48 hours in the laboratory, then gently crushed in an agate mortar to break up larger aggregates, afterward the visible roots were removed and each sample was sieved at $2 \mathrm{~mm}$, homogenized and quartered. Such procedures allowed to homogenize the moisture and roughness of the soil samples, reducing their effect on the spectroscopic measurements.

The relative proportion of sand (2-0.05 
$\mathrm{mm})$, silt $(0.05-0.002 \mathrm{~mm})$, and clay $(<0.002$ $\mathrm{mm}$ ) content was determined through the hydrometer method, after a pre-treatment with sodium hexametaphosphate as a dispersant (Patruno et al. 1997). Then the texture was classified in accordance with the soil texture triangle of the United States Department of Agriculture (USDA 2010 - Fig. 1b).

\section{Laboratory Vis-NIR spectroscopy}

The soil samples sieved at $2 \mathrm{~mm}$ were placed in $9 \mathrm{~cm}$ diameter petri dishes and measures were taken in a black room (to better control irradiance conditions) with an ASD FieldSpec IV 350-2500 nm spectroradiometer (Analytical Spectral Devices Inc., Boulder, Colorado, USA). The instrument combines three spectrometers to cover the solar reflected portion of the spectrum between 350 and $2500 \mathrm{~nm}$, with a sampling interval of 1.4 $\mathrm{nm}$ for the $350-1000 \mathrm{~nm}$ region and $2 \mathrm{~nm}$ for the $1000-2500 \mathrm{~nm}$ region. FieldSpec IV spectra were collected with a resolution of 1 $\mathrm{nm}$, thus producing 2151 spectral bands. A 50 -Watts halogen lamp with a zenith angle of $30^{\circ}$, located at a distance of approximately $25 \mathrm{~cm}$ from the soil sample was used as artificial illumination. The spectroradiometer was located in a nadir position at a distance of $10 \mathrm{~cm}$ from the sample, allowing radiance measurements to be carried out within a circular area of approximately $4.5-\mathrm{cm}$ diameter. To minimize the noise level in the spectral signal, each soil reflectance spectra was recorded as the average of 50 scans carried out consecutively. In addition, to eliminate any possible spectral anomalies due to geometry of measurement, and minimize the possible errors associated with stray light, the measure was repeated 4 times, by rotating each sample 90 degrees $(0,90,180$ and 270 degrees) and the results averaged in post-processing.

A Spectralon panel $\left(20 \times 20 \mathrm{~cm}^{2}\right.$, Labsphere Inc., North Sutton, USA) was used as white reference to compute reflectance values. Under the same measurement conditions a reference spectrum was acquired immediately before the first scan and after every set of five samples.

The average reflectance curves were translated from binary to ASCII with the VIEwSPECPRo software (Analytical Spectral Devices, Inc., Boulder, CO, 80301) and re-sampled each $10 \mathrm{~nm}$ by reducing the number of wavelengths from 2151 to 216 . Resampling smooths the spectra and reduces the risk of over-fitting (Kemper \& Sommer 2002, Shepherd \& Walsh 2002).

\section{Multivariate statistical analysis}

Before performing quantitative statistical analysis, spectral data pre-processing was performed to reduce noise and enhance the absorption frequencies (Martens \& Naes 1989, Næs et al. 2004). The measured reflec- tance $(R)$ spectra were transformed in absorbance through $\log (1 / R)$ to reduce noise, offset effects, and to enhance the linearity between the measured absorbance and soil properties. The absorbance spectra were meancentered to ensure that all results would be interpretable in terms of variation around the mean. Spectra were then smoothed using a Savitzky-Golay filter algorithm, with a second order polynomial and a window size of three, and transformed as first derivative to remove an additive baseline (Viscarra Rossel 2008).

Partial least squares regression (PLSR Geladi \& Kowalski 1986), a common chemometric method in Vis-NIR analysis (Martens \& Naes 1989, Viscarra Rossel et al. 2006), was chosen from the available multivariate statistical methods. The idea behind PLSR is to find a few linear combinations (components or factors) of the original Xvalues (spectral data) and to use only these combinations in the regression equation (Næs et al. 2004). In this way, the irrelevant and unstable information is discarded and only the most relevant part of the X-variation is used for regression; thus the problem of collinearity is solved and more stable regression equations are obtained (Næs et al. 2004). PLSR reduces the Vis-NIR matrix to a small number of statistically significant components. PLSR is based on latent variable decomposition of two sets of variables: the set $\mathrm{X}$ of predictors (matrix $n \times N$, where $n$ is the number of observations and $N$ is the number of wavelengths) and the set $y$ of response variable (vector $n \times 1$ of sand or silt or clay). The latent variables, which are orthogonal factors maximizing the covariance between independent $(\mathrm{X})$ and dependent variables (y), explain most of the variation in both predictors and responses. The optimal number of latent variables was chosen by a one-at-a-time cross-validation as the number that minimizes the predicted residual sum of squares.

Pre-treatment of data and the PLSR procedure were performed using the PARLES v. 3.1 software package developed by Viscarra Rossel (2008).

To test the accuracy of the PLSR regression models the dataset was randomly split into two subsets: the calibration set (including 175 samples, i.e., $75 \%$ of the total dataset) for developing the prediction model, and the validation set (including 60 samples, i.e., $25 \%$ of the total dataset) to test the models' accuracy.

To split the data randomly into two subsets, a value between 0 and 1 was generated simulating a uniform distribution in each sampling location. Then, by selecting the generated values greater than 0.75 a calibration set was created which included $75 \%$ of samples chosen randomly from the data. The complementary selection (values less than
$0.25)$ was included in the validation set ( $25 \%$ of samples).

Leave-one-out cross-validation was used (Efron \& Tibshirani 1993) to test the predictive significance of each PLSR component and to determine the number of factors (latent variables) to be retained in the calibration model. With the leave-one-out cross-validation one sample is left out of the global dataset and the model is calculated on the remaining data points. The value for the leftout sample is then predicted and the prediction residual computed. The above procedure is repeated until every sample has been left out once. To check the goodness of prediction of the leave-one-out cross-validation models, the coefficient of determination $\left(R^{2}\right)$ and the root mean square error (RMSE) were used. The best result for cross validation was considered that showing the lowest RMSE and the highest $R^{2}$.

The models were independently tested through the validation set, and the coefficient of determination $\left(R_{\text {val }}^{2}\right)$ and the root mean square error $\left(\mathrm{RMSE}_{\mathrm{val}}\right)$ were computed to check the goodness of prediction.

\section{Geostatistical approach}

To produce accurate continuous maps of each soil textural fraction, both measured and spectrally predicted values of sand, silt and clay were modeled as an intrinsic stationary process using a geostatistical approach (Chilès \& Delfiner 2012). The quantitative measure of their spatial correlation was the experimental variogram $\gamma(\mathrm{h})$, which is a function of the distance vector $(\mathrm{h})$ of data pairs values separated by a lag vector $h$. A theoretical function, called variogram model, was fitted to the experimental variogram with the aim of building a model that captures the major spatial features of the attribute under study. The variogram model requires two main parameters: range and sill. The range is the distance over which pairs of the three soil texture fractions are spatially correlated, while the sill is the variogram value corresponding to the range. Optimal fitting was chosen on the basis of cross-validation, which checks the compatibility between the data and the model considering each data point in turn, removing it temporarily from the data set and using neighboring information to predict the value of the variable at its location. Goodness-of-fit for the model was based on the mean error $(M E)$ and the mean squared deviation ratio (MSDR - Webster \& Oliver 2007). $M E$ values close to zero indicate unbiased estimates, whereas $M S D R$ values close to 1 indicate a high model accuracy.

The fitted variograms for both measured and spectrally predicted values of sand, silt and clay were used to predict their values at the nodes of a $1 \times 1 \mathrm{~m}$ interpolation grid by ordinary kriging (Webster \& Oliver 2007). 
Tab. 1 - Descriptive statistics of the exhaustive, calibration and validation data sets for the soil textural fractions.

\begin{tabular}{|c|c|c|c|c|c|c|c|c|}
\hline $\begin{array}{l}\text { Textural } \\
\text { fractions }\end{array}$ & Data set & Count & $\begin{array}{c}\text { Mean } \\
(\%)\end{array}$ & $\begin{array}{l}\text { Median } \\
(\%)\end{array}$ & $\begin{array}{l}\text { Minimum } \\
(\%)\end{array}$ & $\begin{array}{c}\text { Maximum } \\
(\%)\end{array}$ & $\begin{array}{c}\text { Standard } \\
\text { deviation }(\%)\end{array}$ & Skewness \\
\hline Sand & Exhaustive & 235 & 42.6 & 42.3 & 17.2 & 81.1 & 11.4 & 0.55 \\
\hline \multirow[t]{2}{*}{$(2-0.05 \mathrm{~mm})$} & Calibration & 175 & 42.5 & 42 & 17.2 & 81.1 & 11.9 & 0.55 \\
\hline & Validation & 60 & 43 & 43.1 & 23.2 & 72.4 & 9.8 & 0.55 \\
\hline Silt & Exhaustive & 235 & 45.9 & 46 & 15.9 & 69.8 & 9.7 & -0.41 \\
\hline \multirow[t]{2}{*}{$(0.05-0.002 \mathrm{~mm})$} & Calibration & 175 & 46.1 & 47 & 15.9 & 69.8 & 9.9 & -0.51 \\
\hline & Validation & 60 & 45.3 & 44.1 & 20.6 & 66 & 8.9 & -0.06 \\
\hline Clay & Exhaustive & 235 & 11.5 & 11.2 & 2.8 & 23 & 3.6 & 0.23 \\
\hline \multirow[t]{2}{*}{$(<0.002 \mathrm{~mm})$} & Calibration & 175 & 11.5 & 11.2 & 2.8 & 23 & 3.6 & 0.21 \\
\hline & Validation & 60 & 11.7 & 11.2 & 3.7 & 20.2 & 3.5 & 0.32 \\
\hline
\end{tabular}

For more details, see Goovaerts (1997), Chilès \& Delfiner (2012), Webster \& Oliver (2007), Wackernagel (2003).

All statistical and geostatistical analyses were performed using the software package IsATIS ${ }^{\circledR}$, release 2013.3 (http://www.geovariances.com).

\section{Results and discussion}

The basic statistics for sand, silt and clay of exhaustive, calibration and validation sets are reported in Tab. 1. The sand content for the exhaustive data set ranges from 17.2 to $81.1 \%$, with a mean value of $42.6 \%$. Most soil samples have a moderate to high sand content and are generally poor in clay (Tab. 1). The silt content varies from 15.6 to 69.8 $\%$, with a mean value of $45.6 \%$, while clay content ranges from 2.8 to $23 \%$, with a mean value of $11.5 \%$. Frequency distribution of the data appears quite symmetric, as revealed by the low values of skewness (Tab. 1).

From the soil texture triangle (Fig. 1b), it appears that soil samples can be mainly classified as sandy loam, loam and silt loam. In addition, Tab. 1 shows that basic statistics for sand, silt and clay in the exhaustive, calibration and validation sets are very similar.
Spectral data analysis and PLSR prediction models for classes of soil texture

The Vis-NIR reflectance spectra of all soil samples shows the typical pattern for different wavelength bands responding to different chemical and/or mineralogical compositions or molecular groups (Demattê \& Terra 2014). In particular, reflectance is generally lower in the visible range $(400-700 \mathrm{~nm})$ and higher in the near infrared $(700-2500 \mathrm{~nm})$ region, with three major specific bands around at 1400, 1900 and $2200 \mathrm{~nm}$. These features can be associated with clay minerals, $\mathrm{OH}$ features of free water at 1400 and $1900 \mathrm{~nm}$, and lattice $\mathrm{OH}$ features at 1400 and $2200 \mathrm{~nm}$ (Ben-Dor 2002, Viscarra Rossel et al. 2006). In addition, the spectra showed a small reflectance peak around 2200 $\mathrm{nm}$, which may be due to organic molecules (e.g., $\mathrm{CH}_{2}, \mathrm{CH}_{3}$, and $\mathrm{NH}_{3}$ ), $\mathrm{SiOH}$ bonds, cation $\mathrm{OH}$ bonds in phyllosilicate minerals (e.g., kaolinite, montmorillonite - Clark et al. 1990).

Results of the visual inspection of spectral curves showed that variations in reflectance intensity and shape of the spectral curves can be due to differences in soil texture due to the correlation between the shape of NIR spectra and soil texture (Mouazen et al.

Fig. 2 - Mean reflectance spectra for different soil texture classes.

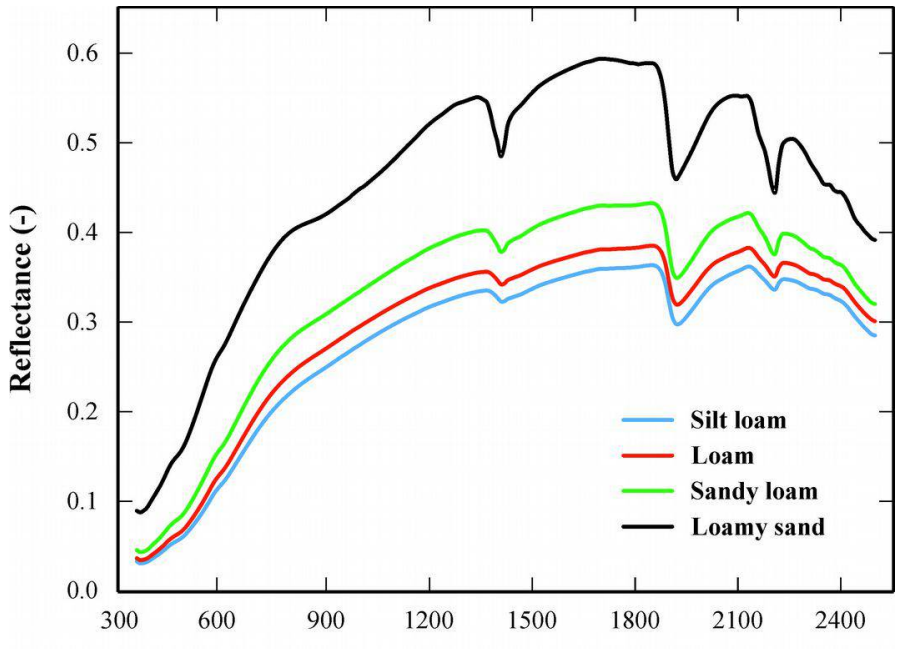

Wavelength (nm)
2005). Fig. 2 shows the mean spectral curves for different soil texture classes. Reflectance was relatively high for soils with loamy sand texture with over $70 \%$ sand content (Fig. 1). This was probably due to the high amount of quartz in the sand fraction, which raised the intensity of spectral reflectance (White et al. 1997). Conversely, the soil reflectance decreased when clay content dominated from phyllosilicates increased (Hill 1994, Palacios-Orueta \& Ustin 1998) and, consequently, the organic carbon content increased (Schwanghart \& Jarmer 2011, Conforti et al. 2013a). Therefore, organic carbon is an important property as regards spectral behavior (Stoner \& Baumgardner 1981, Ben-Dor et al. 1999, Schwanghart \& Jarmer 2011, Conforti et al. 2013a). Generally, the reflectance of soil was found to be relatively low on account of the high content of organic carbon, throughout the Vis-NIR spectral domain.

Cross-validation results of the PLSR models for the three classes of texture are displayed in Fig. 3a. The prediction factors used in the calibration models, selected on the basis of the best cross validation results (lowest $R M S E$ and the highest $R^{2}$ ), were 12 for sand, 10 for silt and 9 for clay. Values of $R^{2}$ ranged between a minimum value of 0.74 for silt and a maximum value of 0.84 for sand, indicating that the models fit quite well.

The validation of the models (Fig. 3b) gave satisfactory results for sand content $\left(R^{2}=\right.$ $0.81)$ and clay content $\left(R^{2}=0.80\right)$, but less stisfactory for silt $\left(R^{2}=0.70\right)$. Moreover, our results were in agreement with those obtained from the cross-validation prediction model, and from many other studies as well (Viscarra Rossel et al. 2006, Volkan Bilgili et al. 2010, Vendrame et al. 2012, Curcio et al. 2013).

\section{Modeling of spatial dependence and} mapping of classes of soil texture

In the analysis of both measured and spectrally predicted sand, silt and clay contents, no anisotropy was evident in the 2-D variogram maps (not shown) up to a maximum lag distance of $450 \mathrm{~m}$. Subsequently, a bounded isotropic nested variogram model was 

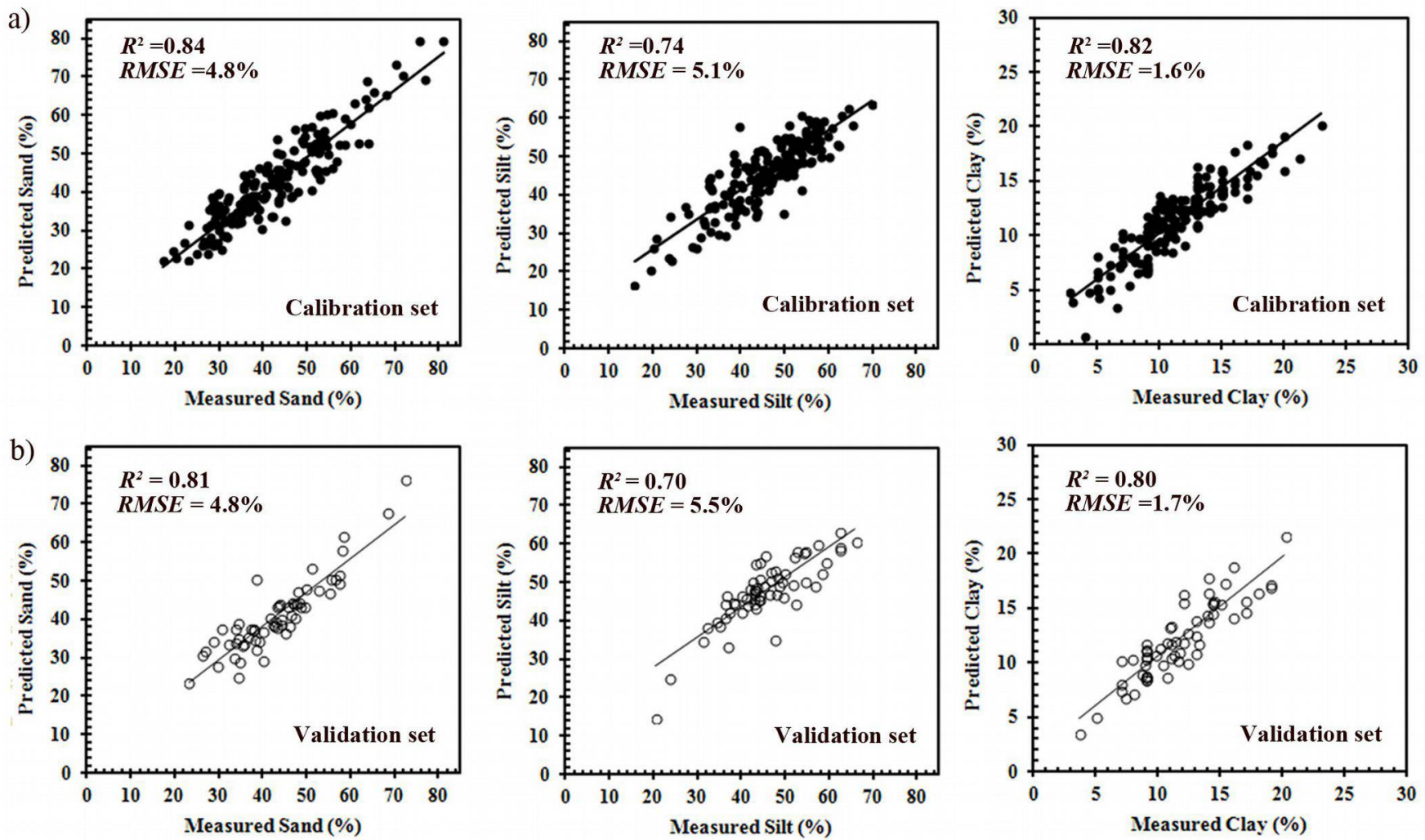

Fig. 3 - Scatter-plots of predicted vs. measured soil textural fractions for the calibration (a) and validation (b) data sets. $\left(R^{2}\right)$ : coefficient of determination; (RMSE): root mean square error.

fitted for each experimental variogram. In the nested model, three basic structures (Tab 2) were combined to include a nugget effect, a spherical model (Webster \& Oliver 2007) at short range and a spherical model at longer range. The nugget effect is a positive intercept of the variogram and arises from errors of measurement and spatial variation within the shortest sampling interval (Webster \& Oliver 2007). The spherical model (Webster \& Oliver 2007) is given by (eqn. $1)$ :

$$
\gamma(h)= \begin{cases}c\left[\frac{3}{2} \frac{h}{a}-\frac{1}{2}\left(\frac{h}{a}\right)^{3}\right] & \text { if } h \leqslant a \\ c & \text { if } h>a\end{cases}
$$

where $c$ is the sill and $a$ the range.

The presence of two ranges (short and long) in the nested model of the variogram means that the physical processes responsible for the variation of soil texture operate and interact at two spatial scales: the short range at about $40-50 \mathrm{~m}$ and the longer range at $280-300 \mathrm{~m}$.

Cross-validation of the variogram models reported in Tab. 2 revealed satisfactory results, in terms of $M E$ and $M S D R$ (close to 0 and 1 , respectively - data not shown). The fitted variogram models were then used with ordinary kriging to produce the maps of sand, silt and clay contents for the measured and spectrally predicted data (Fig. 4). Such maps showed a reasonable spatial similarity, with high and low values matching well (Fig. 4). High sand and low clay content were observed in the upper part of the slopes characterized by low gradient slope and poorly developed soils. Conversely, low values of sand and high content of fine particles (silt and clay) were prevalently observed along the foot of slopes and/or in concave areas where soils are deeper and more developed and, consequently, contain high levels of organic carbon.

Comparing the interpolated maps of measured and spectrally predicted soil texture fractions, it is apparent that the PLSR predictions provided a good representation of the spatial pattern for sand, silt and clay content (Fig. 5). Moreover, as a spatial measure of prediction accuracy, maps of local mismatch were computed as the difference between the maps of measured and spectrally predicted values (Fig. 5). For sand content, $35.2 \%$ of the pixels were overestimated and $64.8 \%$ were underestimated, with a mean difference between measured and spectrally predicted sand content of $0.64 \%$ (min. $-8.5 \%$, max. $8.6 \%$ ). For silt content, $71.6 \%$ of the pixels were overestimated and $28.4 \%$ were underestimated, with a mean difference between measured and spectrally predicted silt content of about $-0.95 \%$ (min. $-11.7 \%$, max. 10.1\%). As regards the clay content, overestimated pixels were $71.8 \%$ and $28.2 \%$ were underestimated; the mean difference between measured and spectrally predicted clay content was about $-0.30 \%$ (min. $-2.4 \%$, $\max .2 .6 \%$ ).

Based on the above results, it is clear that

Tab. 2 - Variogram model parameters for the values of measured (meas) and spectrally predicted (pred) textural fractions.

\begin{tabular}{|c|c|c|c|}
\hline Variable & Model & $\begin{array}{c}\text { Range } \\
\text { (m) }\end{array}$ & $\begin{array}{l}\text { Sill } \\
(\%)\end{array}$ \\
\hline \multirow[t]{3}{*}{ Sand $_{\text {meas }}$} & Nugget & - & 38 \\
\hline & Spherical & 44.06 & 64.91 \\
\hline & Spherical & 290.06 & 26.05 \\
\hline \multirow[t]{3}{*}{ Silt $_{\text {meas }}$} & Nugget & - & 40.39 \\
\hline & Spherical & 46.85 & 42.17 \\
\hline & Spherical & 279.6 & 11.64 \\
\hline \multirow[t]{3}{*}{ Clay $_{\text {meas }}$} & Nugget & 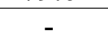 & 4.39 \\
\hline & Spherical & 40.79 & 6.34 \\
\hline & Spherical & 296.32 & 2.12 \\
\hline \multirow{3}{*}{ Sand $_{\text {pred }}$} & Nugget & . & 31.24 \\
\hline & Spherical & 52.98 & 54.75 \\
\hline & Spherical & 291.37 & 32.99 \\
\hline \multirow{3}{*}{ Silt $_{\text {pred }}$} & Nugget & - & 21.42 \\
\hline & Spherical & 54.8 & 40.02 \\
\hline & Spherical & 305.45 & 17.19 \\
\hline \multirow[t]{3}{*}{ Clay $_{\text {pred }}$} & Nugget & - & 3.99 \\
\hline & Spherical & 38.78 & 4.6 \\
\hline & Spherical & 243.76 & 3.32 \\
\hline
\end{tabular}



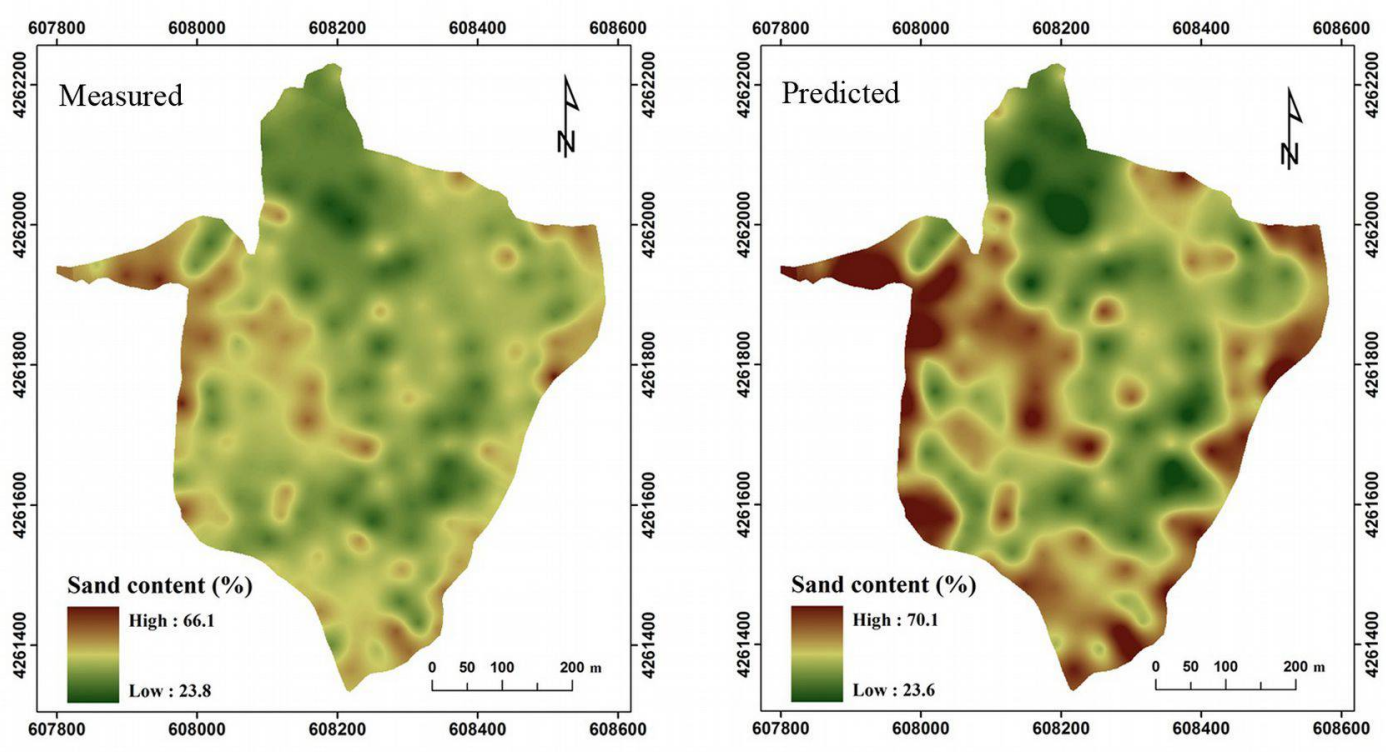

Fig. 4 - Maps of measured (left) and spectrally predicted (right) values for sand (top panels), silt (middle panel) and clay (bottom panels) content in the soil of the study area. Map geographic coordinates are referred to the UTM zone $33 \mathrm{~N}$.
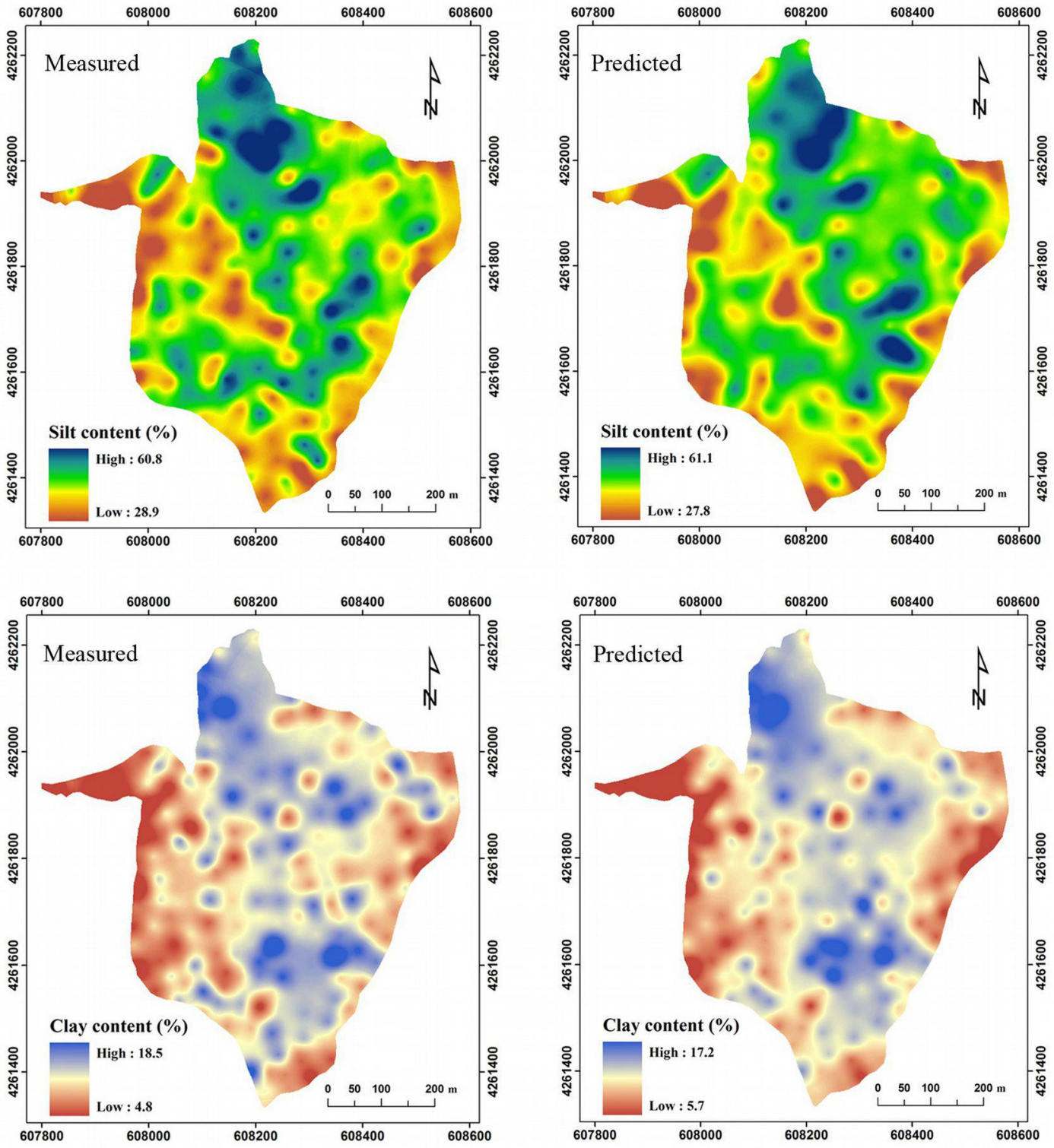

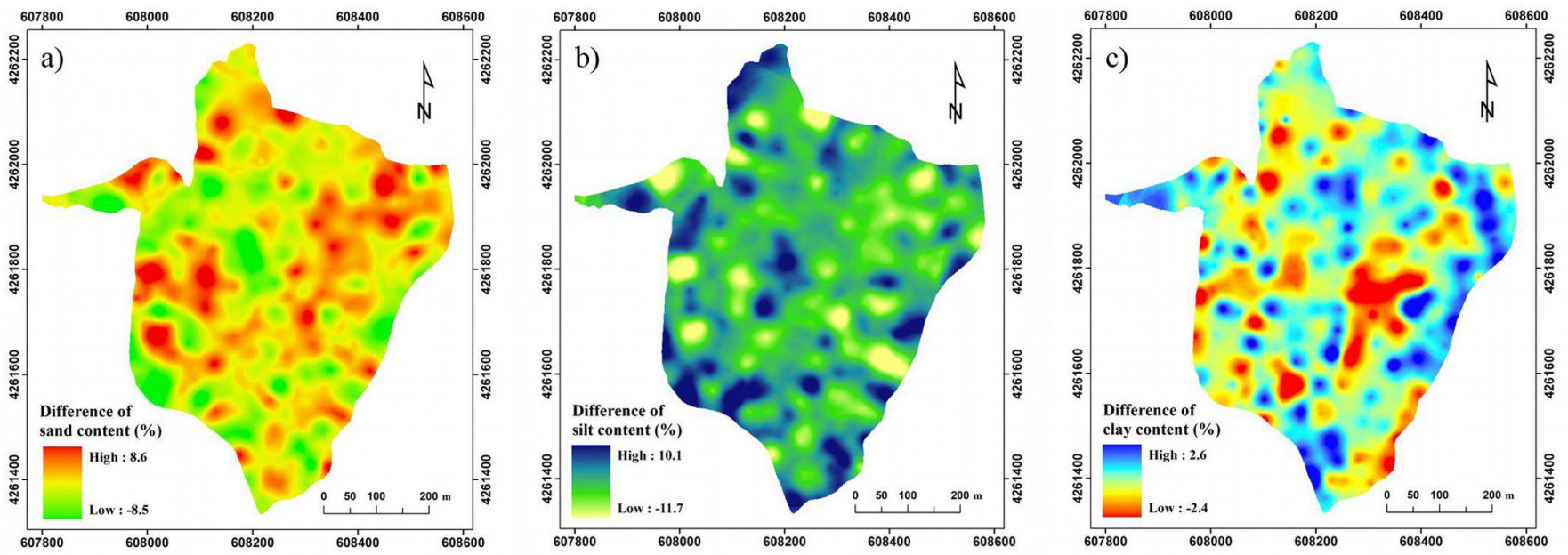

Fig. 5 - Maps of differences between measured and spectrally predicted values for sand (a), silt (b) and clay (c) content in the soil of the study area. Map geographic coordinates are referred to the UTM zone $33 \mathrm{~N}$.

the maps of texture fractions could be used to aid land management decisions; in particular, maps of sand content could be used to identify areas with high drainage and those prone to accelerated nutrient leaching (Lamsal \& Mishra 2010).

\section{Conclusions}

This study confirmed that soil Vis-NIR $(350-2500 \mathrm{~nm})$ reflectance spectra contain valuable information for predicting soil textural fractions (sand, silt, and clay content) Chemometrics techniques and multivariate calibration (PLSR) allowed researchers to extract the relevant information from the reflectance spectra and to correlate this with the soil texture fractions.

Results from cross validation of the calibration models revealed a quite good fitting, with $R^{2}$ varying from a minimum value of $0.74 \%$ for silt to a maximum value of 0.84 for sand content. Also for validation, the results were satisfactory for sand content $\left(R^{2}=\right.$ $0.81)$ and clay content $\left(R^{2}=0.80\right)$ and less satisfactory for silt content $\left(R^{2}=0.70\right)$. Our results were in agreement with those obtained from the cross-validation prediction model, and from many other studies as well.

In conclusion, reflectance spectroscopy in the visible, near infrared $(350-2500 \mathrm{~nm})$ spectral region proved to be a useful alternative to laboratory standard methods for determining the soil textural fractions. By coupling the reflectance spectroscopy approach with geostatistical analysis, map of the spatial pattern for soil texture fractions were obtained, which can be used for better understanding and managing forest soils.

\section{Acknowledgements}

This work was supported by the project LIFE 09ENV/IT/000078 ManFor C.BD. "Managing forests for multiple purposes: carbon, biodiversity and socio-economic wellbeing" and by PONa3_00363 INFRASTRUTTURA AMICA: "Infrastruttura di Alta Tecnologia per il Monitoraggio Integrato Climatico-Ambientale".

The authors thank two anonymous reviewers for their constructive comments on an earlier version of the manuscript. We are grateful to Nicola Ricca for assistance in the fieldwork, and Kevin O'Connel for the English revision of the manuscript.

\section{References}

ARSSA (2003). Carta dei suoli della regione Calabria, scala 1: 250.000 [Soil map of the Calabria region, scale 1:250,000.]. Monografia divulgativa, ARSSA - Agenzia Regionale per lo Sviluppo e per i Servizi in Agricoltura, Servizio Agropedologia, Rubbettino, CS, Italy, pp. 387. [in Italian]

Aïchi H, Fouad Y, Walter C, Viscarra Rossel R, Lili Chabaane Z, Sanaa M (2009). Regional predictions of soil organic carbon content from spectral reflectance measurements. Biosystems Engineering 104 (3): 442-446. - doi: 10.1016/j. biosystemseng.2009.08.002

Ben-Dor E (2002). Quantitative remote sensing of soil properties. Advances Agronomy 75: 173 243. - doi: 10.1016/S0065-2113(02)75005-0

Ben-Dor E, Irons JR, Epema GF (1999). Soil reflectance. In: "Remote Sensing for the Earth Sciences" (Rencz AN ed). Manual of Remote Sensing, vol. 3, Wiley \& Sons, New York, USA, pp. 111-188.

Borsi S, Hieke Merlin O, Lorenzoni S, Paglionico A, Zanettin Lorenzoni E (1976). Stilo unit and "dioritic-kinzigitic" unit in Le Serre (Calabria, Italy). Geological, petrological, geochronological characters. Bollettino della Società Geologica Italiana 95: 219-244.

Bricklemyer RS, Brown DJ (2010). On-the-go VisNIR: potential and limitations for mapping soil clay and organic carbon. Computers and Electronics in Agriculture 70 (1): 209-216. - doi: 10.1016/j.compag.2009.10.006
Buttafuoco G, Conforti M, Aucelli PPC, Robustelli G, Scarciglia F (2012). Assessing spatial uncertainty in mapping soil erodibility factor using geostatistical stochastic simulation. Environmental Earth Sciences 66: 1111-1125. - doi: 10.1007 /s12665-011-1317-0

Calcaterra D, Parise M (2010). Weathering in the crystalline rocks of Calabria, Italy, and relationships to landslides. In: "Weathering as predisposing factor to slope movements" (Calcaterra D, Parise M eds). Geological Society of London, Engineering Geology Series, Special Publication 23, pp. 105-130. [online] URL: http://egsp.lyellcollection.org/content/23/1/105.short

Calcaterra D, Parise M, Dattola L (1996). Caratteristiche dell'alterazione e franosità di rocce granitoidi nel bacino del torrente Alaco (Massiccio della Serre, Calabria) [Characteristics of the weathering and landsliding of granitic rocks in the Alaco torrent basin (Serre Massif, Calabria)]. Bollettino della Società Geologica Italiana 115: 3-28. [in Italian]

Chang CW, Laird DA, Mausbach MJ, Hurburgh CRj (2001). Near-infrared reflectance spectroscopy - principal components regression analysis of soil properties. Soil Science Society of America Journal 65 (2): 480-490. - doi: 10.2136/sssaj2001.652480x

Chilès JP, Delfiner P (2012). Geostatistics: modelling spatial uncertainty. Wiley, New York, USA, pp. 695.

Clark RN, King TVV, Klejwa M, Swayze GA (1990). High spectral resolution reflectance spectroscopy of minerals. Journal of Geophysical Research 95: 653-680. - doi: 10.1029/JB095iB08p 12653

Conforti M, Buttafuoco G, Leone AP, Aucelli PPC, Robustelli G, Scarciglia F (2012). Soil erosion assessment using proximal spectral reflectance in VIS-NIR-SWIR region in sample area of Calabria region (Southern Italy). Rendiconti Online Società Geologica Italiana 21 (Part 2): 12021204.

Conforti M, Buttafuoco G, Leone AP, Aucelli 
PPC, Robustelli G, Scarciglia F (2013a). Studying the relationship between water-induced soil erosion and soil organic matter using Vis-NIR spectroscopy and geomorphological analysis: a case study in a southern Italy area. Catena 110: 44-58. - doi: 10.1016/j.catena.2013.06.013

Conforti M, Froio R, Matteucci G, Caloiero T, Buttafuoco G (2013b). Potentiality of laboratory visible and near infrared spectroscopy for determining clay content in forest soil: a case study from high forest beech (Fagus sylvatica) in $\mathrm{Ca}$ labria (southern Italy). EQA - International Journal of Environmental Quality 11: 49-64. [online] URL: http://eqa.unibo.it/article/view/4172/0 Curcio D, Ciraolo G, D’Asaro F, Minacapilli M (2013). Prediction of soil texture distributions using VNIR-SWIR reflectance spectroscopy. Procedia Environmental Sciences 19: 494-503. doi: 10.1016/j.proenv.2013.06.056

Curran PJ (1994). Imaging spectrometry. Progress in Physical Geography 18: 247-266. - doi: 10.11 77/030913339401800204

Demattê JAM, Terra FS (2014). Spectral pedology: a new perspective on evaluation of soils along pedogenetic alterations. Geoderma 217 218: 190-200. - doi: 10.1016/j.geoderma.2013. 11.012

Efron B, Tibshirani R (1993). An introduction to the bootstrap. Monographs on statistics and applied probability, vol. 57, Chapman and Hall, London, UK, pp. 436.

Ehsani MR, Upadhyaya SK, Slaughter D, Shafii S, Pelletier M (1999). A NIR technique for rapid determination of soil mineral nitrogen. Precision Agriculture 1: 217-234. - doi: 10.1023/A:10099 16108990

Farifteh J, Van Der Meer F, Atzberger C, Carranza EJM (2007). Quantitative analysis of saltaffected soil reflectance spectra: a comparison of two adaptive methods (PLSR and ANN). Remote Sensing of Environment 110: 59-78. - doi: 10.10 16/j.rse.2007.02.005

Ge Y, Thomasson JA, Morgan CL, Searcy SW (2007). VNIR diffuse reflectance spectroscopy for agricultural soil property determination based on regression-kriging. American Society of Agricultural and Biological Engineers 50: 10811092. [online] URL: http://www2.bonsaiadvanced.com/Regressionkriging.pdf

Geladi P, Kowalski BR (1986). Partial least-squares regression: a tutorial. Analytica Chimica Acta 185: 1-17. - doi: 10.1016/0003-2670(86)800289

Goovaerts P (1997). Geostatistics for natural resources evaluation. Oxford University Press, New York, NY, USA, pp. 483. [online] URL: http://books.google.com/books?id=CW-7tHAa VR0C

Hill J (1994). Spectral properties of soils and the use of optical remote sensing systems for soil erosion mapping. In: "Chemistry of Aquatic Systems: Local and Global Perspectives" (Bidoglio G, Stumm W eds). ECSC, EEC, EAEC, Brussels and Luxembourg, pp. 497-526. - doi: 10.1007/ 978-94-017-1024-4 18

Kemper T, Sommer S (2002). Estimate of heavy metal contamination in soils after a mining accident using reflectance spectroscopy. Environmental Science and Technology 3: 2742-2747. doi: $10.1021 / \mathrm{es} 015747 \mathrm{j}$

Knadel M, Stenberg B, Deng F, Thomsen A, Greve M (2013). Comparing predictive abilities of three visible-near infrared spectrophotometers for soil organic carbon and clay determination. Journal of Near Infrared Spectroscopy 21: 67-80. - doi: 10.1255/jnirs. 1035

Köppen W (1936). Das geographische System der Klimate [The current system of climates]. In: "Handbuch der Klimatologie. Band 5" (Köppen W, Geiger R, Teil C eds). Gebrüder Bornträger, Berlin, Germany, pp 1-46. [in German]

Lal R (2005). Forest soils and carbon sequestration. Forest Ecology and Management 220: 242258. - doi: 10.1016/j.foreco.2005.08.015

Lamsal S, Mishra U (2010). Mapping soil textural fractions across a large watershed in north-east Florida. Journal of Environmental Management 91:1686-1694. - doi: 10.1016/j.jenvman.2010. 03.015

Leone AP, Sommer S (2000). Multivariate analysis of laboratory spectra for the assessment of soil development and soil degradation in the Southern Apennines (Italy). Remote Sensing of Environment 72: 346-359. - doi: 10.1016/S00344257(99)00110-8

Martens H, Naes T (1989). Multivariate calibration. John Wiley \& Sons, Chichester, UK, pp. 438. [online] URL: http://books.google.com/ books?id $=61 \mathrm{VcUeVDg} 9 \mathrm{IC}$

Matheron G (1971). The theory of regionalised variables and its applications. Les Cahiers du Centre de Morphologie Mathématique n. 5, Fontainebleau, France, pp. 271.

McDowell ML, Bruland GL, Deenik JL, Grunwald S, Knox NM (2012). Soil total carbon analysis in Hawaiian soils with visible, near-infrared and mid-infrared diffuse reflectance spectroscopy. Geoderma 189-190: 312-320. - doi: 10.10 16/j.geoderma.2012.06.009

Mouazen AM, Karoui R, De Baerdemaeker J, Ramon H (2005). Classification of soil texture classes by using soil visual near infrared spectroscopy and factorial discriminant analysis techniques. Journal of Near Infrared Spectroscopy 13: 231-240. - doi: 10.1255/jnirs.541

Nanni MR, Demattê JAM (2006). Spectral reflectance methodology in comparison to traditional soil analysis. Soil Science Society of America Journal 70: 393-407 - doi: 10.2136/sssaj2003.02 85

Næs T, Isaksson T, Fearn T, Davies T (2004). A user-friendly guide to multivariate calibration and classification. Reprinted with corrections. NIR Publications, Chichester, UK, pp. 344.

Osman KT (2013). Soils. Principles, properties and management. Springer Science+Business Media, Dordrecht, The Neteherlands, pp. 271. doi: 10.1007/978-94-007-5663-2

Palacios-Orueta A, Ustin SL (1998). Remote sensing of soil properties in the Santa Monica mountains I. Spectral analysis. Remote Sensing of Environment 65: 170-183. - doi: 10.1016/S00
34-4257(98)00024-8

Patruno A, Cavazza L, Castrignanò A (1997). Granulometria [Granulometry]. In: "Metodi di analisi fisica del suolo. III.1", (Pagliai M ed). Franco Angeli, Rome, Italy, pp. 1-26. [in Italian] Schwanghart W, Jarmer T (2011). Linking spatial patterns of soil organic carbon to topography - A case study from south-eastern Spain. Geomorphology 126: 252-263. - doi: 10.1016/j.geomor ph.2010.11.008

Shepherd KD, Walsh MG (2002). Development of reflectance spectral libraries for characterization of soil properties. Soil Science Society of America Journal 66: 988-998. - doi: 10.2136/sssaj20 02.9880

Silver WL, Neff J, McGroddy M, Veldkamp E, Keller M, Cosme R (2000). Effects of soil texture on belowground carbon and nutrient storage in a lowland Amazonian forest ecosystem. Ecosystems 3: 193-209. - doi: 10.1007/s1002100000 19

Sorriso-Valvo M (1993). The geomorphology of Calabria. A sketch. Geografia Fisica e Dinamica Quaternaria 16: 75- 80.

Stenberg B, Viscarra Rossel RA, Mouazen AM, Wetterlind J (2010). Visible and near infrared spectroscopy in soil science. Advances in Agronomy 107: 163-215. - doi: 10.1016/S0065-2113 (10)07005-7

Stoner ER, Baumgardner MF (1981). Characteristic variations in reflectance of surface soils. Soil Science Society of America Journal 45: 11611165. - doi: 10.2136/sssaj1981.0361599500450 00 z60031x

Sørensen LK, Dalsgaard S (2005). Determination of clay and other soil properties by near infrared spectroscopy. Soil Science Society of America Journal 69:159-167. - doi: 10.2136/sssaj2005.01 59

Telles ECC, Camargo PB, Martinelli LA, Trumbore SE, Costa ES, Santos J, Higuchi N, Oliveira RCJ (2003). Influence of soil texture on carbon dynamics and storage potential in tropical forest soils of Amazonia. Global Biogeochemical $\mathrm{Cy}$ cles 17 (2): 1040. - doi: 10.1029/2002GB001953 Udelhoven T, Emmerling C, Jarmer T (2003). Quantitative analysis of soil chemical properties with diffuse reflectance spectrometry and partial least-square regression: a feasibility study. Plant and Soil 251: 319-329. - doi: 10.1023/A:102300 8322682

USDA (2010). Keys to soil taxonomy (11 $1^{\text {th }}$ edn). Soil Survey Staff, USDA Natural Resources Conservation Service, Washington, DC, USA, pp. 344. [online] URL: http://books.google.com/ books? id $=\mathrm{CuWEKWc} 1 \mathrm{wIgC}$

Vendrame PRS, Marchao RL, Brunet D, Becquer $\mathrm{T}$ (2012). The potential of NIR spectroscopy to predict soil texture and mineralogy in Cerrado Latosols. European Journal of Soil Science 63 (5): 743-753. - doi: 10.1111/j.1365-2389.2012.0 1483.x

Viscarra Rossel RA, McBratney AB (1998). Laboratory evaluation of a proximal sensing technique for simultaneous measurement of soil clay and water content. Geoderma 85: 19-39. - doi: 
10.1016/S0016-7061(98)00023-8

Viscarra Rossel RA, Walvoort DJJ, McBratney AB, Janik LJ, Skjemstad JO (2006). Visible, near-infrared, mid-infrared or combined diffuse reflectance spectroscopy for simultaneous assessment of various soil properties. Geoderma 131: 59-75. - doi: 10.1016/j.geoderma.2005.03.007 Viscarra Rossel RA (2008). ParLeS: software for chemometrics analysis of spectroscopic data. Chemometrics and Intelligent Laboratory Systems 90: 72-83. - doi: 10.1016/j.chemolab.2007. 06.006

Viscarra Rossel RA, McBratney AB (2008). Diffuse reflectance spectroscopy as a tool for digital soil mapping. In: "Digital Soil Mapping with Limited Data" (Hartemink AE, McBratney AB, Mendonça-Santos L eds). Elsevier Science, Amsterdam, The Netherlands, pp. 165-172.

Viscarra Rossel RA, Behrens T (2010). Using data mining to model and interpret soil diffuse reflectance spectra. Geoderma 158: 46-54. - doi: 10.1016/j.geoderma.2009.12.025

Volkan Bilgili A, van Es HM, Akbas F, Durak A, Hively WD (2010). Visible-near infrared reflectance spectroscopy for assessment of soil properties in a semiarid area of Turkey. Journal of Arid Environments 74: 229-238. - doi: 10.1016/j.jaridenv.2009.08.011

Wackernagel H (2003). Multivariate geostatistics: an introduction with applications. Springer, Berlin, Germany, pp. 387. [online] URL: http:// books.google.com/books?id=Rhr7bgLWxx4C

Waiser TH, Morgan CLS, Brown DJ, Hallmark CT (2007). In situ characterization of soil clay content with visible near-infrared diffuse reflectance spectroscopy. Soil Science Society of America Journal 71: 389-396. - doi: 10.2136/sssaj2006.0211

Webster R, Oliver MA (2007). Geostatistics for environmental scientists $\left(2^{\text {nd }}\right.$ edn). Wiley, Chi- chester, UK, pp. 330. [online] URL: http://books.google.com/books?id=WBwSyvIvNY8C

Wetterlind J, Stenberg B, Söderström M (2008).

The use of near infrared (NIR) spectroscopy to improve soil mapping at the farm scale. Precision Agriculture 9: 57-69. - doi: 10.1007/s1111 9-007-9051-z

White K,Walden J, Drake N, Eckardt F, Settle J (1997). Mapping the iron oxide content of dune sands, Namib Sand Sea, Namibia, using Landsat Thematic Mapper data. Remote Sensing of Environment 62: 30-39. - doi: 10.1016/S0034-4257 (97)00068-0

Yang H, Griffiths PR, Tate JD (2003). Comparison of partial least squares regression and multilayer neural networks for quantification of nonlinear systems and application to gas phase Fourier transform infrared spectra. Analytica Chimica Acta 489: 125-136. - doi: 10.1016/S00032670(03)00726-8 